Tattva, Vol. 3, No. 1, January - June 2017, pp. 91-712 ISSN 0975-332X | https://doi.org/10.12726/tjp.5.7

Tattua

JOURNAL OF PHILOSOPHY

\title{
MYSTICISM WITHOUT BOUNDS: JACOB BOEHME, WILLIAM BLAKE AND JUNG'S PSYCHOLOGY
}

\section{Patrick Menneteau, Ph.D}

It may seem paradoxical to falk about mysticism, because the term is usually connected with theme of forbidden knowledge (as symbolized by the tree of Eden). Mystics generally insist on the inaccessibility of the mystical experience to thought and language: such is the case with the Deus absconditus of Master Eckhart, but also with Grégoire de Nisse, or again with Pseudo Denys, in his Mystical Theology. From the anonymous $17^{\text {th }}$ century Theologia Germanica, we may catch a glimpse of this ineffable overwhelming moment:

But if the 'One', who is also the 'Whole', seizes a creature and submits it, if this creature seems to him well-disposed and adequate for him to recognize himself in it, being a will and a love, a light and a knowledge, he learns by himself that he must desire nothing but the "One" whom he is.'

1 Théologie Germanique, (ed. M. Windstosser). Paris : Arma Artis, 1911, 175 :Mais si cet "Un", qui est en même temps le "Tout», s'empare d'une créature, s'il se la soumet et si cette créature lui paraît bien disposée et convenable pour qu'il se reconnaisse lui-même en elle, étant une volonté ef un amour, étant une lumière ef une connaissance, il apprend de lui-même qu'il ne doit rien désirer que cet uUn» qu'il est. 
Jacob Boehme, in the $17^{\text {th }}$ century, describes the ultimate "reality" of God in terms of nothingness: "He is the One who is also the eternal Nothing [...] he is incommensurate ${ }^{\prime \prime}$; "the eternal and divine intelligence is a free will [...] she is the Whole and yet is only, so to speak, Nothingness" ${ }^{\prime \prime}$. Hence the possibly disheartening observation of $20^{\text {th }}$ century philosopher Guy Lardreau, who sums up the problem in the following terms, by reference to the writings of $6^{\text {th }}$ century mystic Philoxène de Mabbourg:

The paradox of spiritual literature: about that on which this 'life', the subject of long and well-codified discourses, is ordered and qualified by; about the end of these practices that are constantly fed by the numberless mass of apophthegms, lives of saints, rules, lectures and directories, in one word, about contemplation, nothing can be said: so many speeches, so ordered and constrained, to reach nothing but silence. The ineffable character of this experience - ineffable in as much as it is precisely an experience, for who has not lived it can endlessly talk about it: this is the definition of the philosopher -, there lies [...] in the end, the essential. A singular experience which each spiritual man lives next to the others, and which is so radically singular that it is properly through it that he becomes himself a singularity: what did they see, and how, we will never know. ${ }^{4}$

Through this echo to the archetypal theme of forbidden knowledge, man does not seem to be meant to know about divine matters: indeed, Adam and Eve were punished for eating of the apple of the Tree of knowledge in Eden; lcarus burnt his wings while trying to approach the sun; Semele died when Zeus appeared to her in

2 Jacob Boehme, Mysterium Magnum (1623). Plan de la Tour : Editions d'aujourd'hui, 1978, vol l, 55 and $57:$ : Il est I'Un qui est en même temps le Rien éternel [...] il est incommensurable»

3 Ibid, vol II, 336: "L'intelligence éternelle et divine est une libre volonté [...] elle est Tout et pourtant n'est pour ainsi dire qu'un Néant"

4 Guy Lardreau, Discours philosophique et discours spirituel : autour de la philosophie spirituelle de Philoxène de Mabbourg, Paris: Sevil, 1985, 99 : Paradoxe de la littérature spirituelle : de cela même à quoi cette 'vie', dont on peut si longuement parler, et de manière si codifiée, est ordonnée, et qui la qualifie; de la fin à quoi tend cette pratique qu'inlassablement instruit la masse incalculable des apophtegmes, des vies des saints, des règles, des conférences et des directoires; bref, de la contemplation, on ne peut rien dire : tant de paroles, ef si réglées, si contraintes, pour aboutir au silence. Le caractère ineffable de celte expérience - ineffable dans la mesure même où elle est une expérience, car qui ne l'a point faite en peut parler indéfiniment : cela s'appelle un philosophe - , là est bien [...] en fin de compte, l'essentiel. Une expérience singulière, que chaque spirituel fait à côté des autres, el si radicalement singulière que $c^{\prime}$ est en elle, proprement, qu'il advient comme singularité : que voyaient-ils, comment voyaient-ils? Nous ne le saurons jamais. 
his splendour; Actaeon was devoured by his own hounds for having caught sight of Artemis in her nakedness, and similar misadventures befell Tantalus, Phaeton, and Bellerophon. In all these cases, the hero was punished for attempting to reach some kind of divine prerogative. Does such a difficulty imply that mysticism is to remain totally unconnected from everyday life? I would like to suggest that one means of going round this difficulty is to read mystical texts in psychological terms, bearing in mind a fundamental distinction between Sigmund Freud and Carl Gustav Jung.

Indeed, it would sometimes be tempting, in a Freudian vision, to read mystical texts as mere "projections" of our own subconscious, thus reducing every kind of mysticism to matters of sexual fantasies. The description of the first manifestation out of "nothingness", the primal matrix, by $16^{\text {th }}$ century German theosopher Jacob Boehme does lend itself to such an interpretation: Will, the first manifestation of divine nothingness, is desire. And this desire begets within itself a thorn which, as it grows and swells, starts to oppose the desire that begot it in a contradictory movement, the account of which would equally suit a sexual act: a symbolic phallus exciting a desiring matrix. ${ }^{5}$ In the same way, it would be easy to read William Blake's description of the moment of the final resurrection in terms of sexual pröjections:

5 Jacob Boehme. De la Triple vie de l'homme (written in 1620, published in 1682). Plan de la Tour : Editions d'Aujourd'hui, 1982, pp. 26-36: " Il y a deux volontés dans un seul être, et elles occasionnent deux principes ; l'un est l'amour, l'autre est colère [...] La volonté du Père est la première dans l'éternité [...] or telle est le propre de la volonté ou du centre, c'est particulièrement de désirer d'engendrer la parole ou le cœur : car autrement il n'y auroit rien [...]. Le désir est astringent et attirant car il est la force serrant le large en étroit [...]. Ainsi le désir attire à soi $[\ldots]$ et l'attiré est l'empressement du désir, et le désir fait plaire, et là cependant il n'y a rien qu'un ténèbre ; [...] la volonté mince est comme un rien et entièrement tranquille; mais le désir la rend pleine, et cet attiré dans le désir est les essences ou l'aiguillon de la sensibilité qui combat l'enfermement, lequel le désir ne peut pas supporter, et attire $d^{\prime}$ autant plus fort à soi ; ainsi l'aiguillon en devient plus grand et s'emporte contre l'attiré, et ne peut cependant pas en sortir car le désirl'engendre, ef ne peut cependant pas l'endurer, car c'est une inimitié comme le chaud et le froid. Alors l'attract devient aussi astringent et fortement attirant pour contenir l'aiguillon, d'où il donne la mobilité comme une vie en mouvement [...] car dans l'angoisse de l'attract, dans le dur attirant, il s'élève une forte froideur, et ce tiré est son aiguillon astringent amer, de façon qu'il donne une puissance effroyablement forte que l'aiguillon ne peut pas souffrir, [...] et comme il ne peut pas s'échapper au dessus de soi, il devient tournant comme une roue, ef disperse I'astringent d'où résultent les essences de la multiplicité. L'éclair du feu fait la troisième forme dans la nature [...] et l'âme ou l'éternelle vie est la quatrième forme. [...] Ainsi les quatre formes de la nature ne s'appellent plus le centre, quoiqu'elles aient le centre en elles dans leur original [...] et l'angoisse fait une seconde volonté en soi, de façon que les quatre formes ont en ellesmêmes une éłernelle volonté qui leur est propre, " 
The Grave shrieks with delight \& shakes

Her hollow womb \& clasps the solid stem:

Her bosom swells with wild desire,

And milk \& blood \& glandous wine

In rivers rush \& shout \& dance,

On mountain, dale and plain. ${ }^{6}$

Jung, as to him, refused to limit the libido to the sexual definition given by Freud and sought to explain the power of fascination of these writings and illustrations in terms of the manifestation of a "reality" that lies much deeper within human nature, beyond the varieties of religious discourses or ideological values, and beyond the concerns of the individual subconscious: an objective psyche in which the images of a collective subconscious form the legacy of the fundamental experiences of the human species, the libido being a form of psychic energy at play in moments of inspiration. ${ }^{7}$ I would like to propose, therefore, that we study what his theories have to say about mysticism, along the following lines: (1) some parallels between Jung and mysticism, (2) mysticism without bounds: a possibility or a danger: the psychological dimension of mysticism, and (3) the mystical dimension of psychology: "mysticism unbound".

\section{1) Parallels between Jung and Mysticism}

To Jung, mystical discourses are the only empirical elements we can take as objects of study if we have no access to any direct mystical experience. And in the course of the analysis, many striking parallels appear between Jung's ideas and mystical themes. For instance, one of the main themes that are common to mystical authors is the complaint about the shortcomings and inefficiencies of human language. William Blake talks of the English language as "the rough basement" and complains:

6 William Blake, Complete Writings (1783-1820) (ed. Geoffrey Keynes). Oxford University Press, 1972, 248: The Song of Los. See also his illustration «Christ in the Sepulchre, guarded by Angels", in which one can easily identify the picture of a phallus.

7 See C.G. Jung, Le Divin en l'homme. Paris : Albin Michel, 1999, 481 : « La langue prophétique $n^{\prime}[a]$ pas selon moi sa source dans l'imagination personnelle mais dans les représentations collectives. Comme dans les grandes ceuvres littéraires, les expériences religieuses et les visions prophétiques, la source originelle est à chercher ici [dans le cas d'Osée] dans des représentations archétypiques qui n'ont que peu de rapport avec la disposition individuelle du poète." 
$O$, how can I with my gross tongue that cleaveth to the dust

Tell of the Four-fold Man in starry numbers fitly order'd,

Or how can I with my cold hand of clay! ${ }^{8}$

Jacob Boehme, as to him, observes that in the wake of Adam's fall, our language became "coarse and beastly": 9 this is why he can only invite his reader to some kind of spiritual reading that reaches beyond the words of a deliberately obscure language.$^{10}$ Thus, it becomes apparent that the difficulty in reading Blake's prophetic poems or Boehme's theosophical treatises finds its source in a common conviction in mystical authors, according to whom nothing can replace experience itself: mysticism is primarily a matter of inner experience.

It should be noted that Jung's rational approach is based on his clinical experience, and that a number of empirical clues point to the validity of this working hypothesis: dreams may reveal archetypal manifestations, but, as his works abundantly show, archetypal forms can also be found in many types of discourses belonging to various cultures and fields: mythology, alchemy, mysticism, metaphysics, and sciences. "Events of synchronicity can be experienced by everyone of us and rest on the same ground as the ancestral practice of the Chinese Yi-King: the concept of a dual reality, both material and supra-material, an echo of which is to be found in the Unus Mundus of the alchemists. As soon as he started to explore these perspectives, Jung no longer met the scientific requirements to which Freud wanted to submit the new theories of psychoanalysis. Why did Freud, although he had found in a myth the perfect illustration of his Oedipus complex, refrain from studying mythologies and the field of the "occult"? It does seem as though he was under the influence of the scientific model, which, phenomenologically speaking, and from a Jungian point of view, stands for the prevalence of "sensation" and "reflection" at the expense of the other two faculties of the mind: feeling (which is not acknowledged as the ultimate ground for even our "rational" choices, despite David Hume's considerations on subjectivity), and intuition (which is nevertheless regarded as the gateway towards the unconscious). Whereas Freud was keen on keeping a scientific

8 William Blake, Complete Writings, p. 668 and 502.

9 Jacob Boehme, Mysterium Magnum, vol. 1, 82: “ Nous avons posé avec l'esprit de notre connaissance un solide cadenas devant la compréhension de la folie [de ce monde], afin qu'elle ne comprît pas notre idée. [...] Chacun n'a done qu'à voir ce dont il est capable, et chacun en tirera son profit..."

10 Ibid, vol. I, 53-4.

11 See, for instance: Cazenave, Michel, La Science ef les figures de l'âme. Monaco, éd. Du Rocher, 1996. 
persona, Jung focussed on inner experience as a guide, as he acknowledged particularly in his later writings:

This is why the conversations with the dead, the "Seven Sermons", are a kind of prelude to what I had to communicate to the world about the subconscious: They are a kind of ordering pattern and an interpretation of the general contents of the subconscious. (...) I can state today that i never distanced myself from my initial experiences. All my works and all that I have created in the field of the mind spring from the original fancies and dreams. ${ }^{12}$

The focus on inner experience, despite the paradox of mystical discourses, leads us to face once more the question: what can be said about this inner experience? William Blake first invites his readers to distinguish Locke's concept of experience (that is, empirical experiment, based on the observation of the outside world) from the inner experience of the subject, which he calls "the faculty which experiences": "As the frue method of knowledge is experiment, the faculty of knowing must be the faculty which experiences. This faculty I treat of" (K98).

In so doing, he symbolizes a turning point in the history of ideas which is equally exemplified, in the field of philosophy, by David Hume's criticism of empiricism. Indeed, in his Treatise on Human Nature, the philosopher establishes that in the last analysis, even a discourse such as that of empiricism (with it claim to objectivity, and which was to become the basic method of modern science) is steeped in subjective roots:

[...] an opinion or belief is nothing but an idea, that is different from a fiction, not in the nature, or the order of its parts, but in the manner of its being conceiv'd. But when I wou'd explain this manner, I scarce find any word that fully answers the case, but am oblig'd to have recourse to every one's feeling, in order to give him a perfect notion of this operation of the mind. An idea assented to feels different from a fictitious idea that the fancy alone presents to us: And this different feeling, I endeavour to explain by calling it a superior force, or vivacity, or solidity, or firmness, or steadiness. This variety of terms, which may seem so unphilosophical,

12 Jung, C.G., Ma Vie (1961). Paris : Gallimard, 1973, 223 : C'est pourquoi les conversations avec les morts, les "Sept sermons", forment une sorte de prélude à ce que j'avais à communiquer au monde sur l'inconscient : ils sont une sorte de schéma ordonnateur et une interprétation des contenus généraux de l'inconscient. [...] Je puis dire aujourd'hui que je ne me suis jamais éloigné de mes expériences initiales. Tous mes travaux, tout ce que j'ai crée sur le plan de l'esprit proviennent des imaginations ef des rêves initiaux. 
is intended only to express that act of the mind, which renders realities more present to us than fictions, causes them to weigh more in the thought, and gives them a superior influence on the passions and imagination. ${ }^{13}$

Hume's concept of the feeling of truth was to be taken up by Husserl's phenomenology, and finds an echo in Guy Lardreau's experimentum mentis:

All this can, it seems to me, be confirmed in yet another way, and at another level: by asking whence comes to the philosopher, when meeting with some truth, the certainty of being in front of a truth? He may hold this link firmly because he is sure of having tested the strength of a previous one, and because that one was yet again confirmed by a first: it is nevertheless necessary that at the very end the entire chain originate in an experimentum mentis which it cannot account for, since reason started from it, and whose insistence should legitimately be tested, although it grows weaker and weaker with every link, yet being taken up in each of them, at every moment. This experience, from which, in the last analysis, spring all philosophical statements, why should we not give it the name, which it too clearly claims, from Descartes to Nietzsche, of an illumination? ${ }^{14}$

This moment of illumination (which can be compared to the scientist's "insight" as studied by Rudolph Carnap in the Vienna school of the philosophy of science),,$^{15}$

13 David Hume, A Treatise of Human Nature (1739). Oxford: Clarendon Press, 1983, 628: footnote intended for page 96.

14 Guy Lardreau, Discours philosophique et discours spirituel, 142-3: Tout cela se peut, il me semble, confirmer encore d'un autre biais, et à un autre niveau : à demander d'où vient au philosophe la certitude où il est de se trouver, lorsqu'il la rencontre, devant une vérité. II peut bien tenir ce maillon assuré d'avoir éprouvé la solidité du précédent, et que celle-ci lui est encore par un premier garantie : il faut bien qu'à la fin des fins la chaîne entière trouve son origine dans un experimentum mentis dont elle ne rend pas raison, puisque la raison est à partir de lui, et dont l'insistance, en droił, doit pouvoir s'éprouver, même si de fait elle s'affaiblit de maillon en maillon, en chacun d'eux pourtant, à tout moment ressaisie. Cette expérience, dont tout philosophème relève en dernière instance, pourquoi ne pas lui donner le nom que, de Descartes à Nietzsche, trop clairement elle réclame, d'une illumination?

15 See Rudolph Carnap, "Theories and Nonobservables" in J. Fetzer, ed. Foundations of Philosophy of Science. New-York: Paragon House, 1993, p. 107: It must not be forgotten that, both in the history of science and in the psychological history of a creative scientist, a theory has often first appeared as a kind of visualization, a vision that comes as an inspiration to a scientist long before he has discovered correspondence rules that may help in confirming his theory. When Democritus said that everything consists of atoms, he certainly had not the slightest confirmation for this theory. Nevertheless it was a stroke of genius, a profound insight, because two thousand years later his vision was confirmed. 
establishes the similarity between the subjective roots of all discourses alike (whether religious, mystical, philosophical or indeed scientificl). Hume's subjectivism thus opened the questioning of Locke's over-simplistic view of perceptions leading to impressions (ideas) in the tabula rasa of the mind:

Thus all probable reasoning is but a species of sensation. 'Tis not solely in poetry and music, we must follow our taste and sentiment, but likewise in philosophy. When I am convinced of any principle, 'tis not only an idea, which strikes more strongly upon me. When I give the preference to one set of arguments above another, I do nothing but decide from my feeling concerning the superiority of their influence. ${ }^{16}$

Today, this criticism has even spread to the field of economics, which also has claims to scientific truth (via the cult of mathematical models), but which some economists expose as being under the determinant influence of irrational factors. ${ }^{17}$ Thus, all systems of human knowledge, all systems of explanation of the world, all claims to objective truth are liable to this radical questioning. Whereas Locke rejected past metaphysical systems as mere matters of opinion, ${ }^{18}$ Jung is now in a position to expose Locke's empiricism as prejudice:

A general form of prejudice has it that $\Lambda[. .$.$] the ultimate ground for our$ knowledge be exclusively given from outside, and that nihil esse in intellectu quod non antea fuerit in sensu. And yet [...) all those who know the old science or old natural philosophy know what part of psychic data is projected onto the unknown of the outside phenomenon. This part is so great that in the end we can never tell how the world in itself is eventually made, for we are indeed compelled to transpose the physical element into a psychic process, as soon as we mean knowledge. [...] It

16 Ibid., 103.

17 See le Manifeste d'Economistes Atterrés, by a number of distinguished economists and academics analysing the roots of the last recession (www.assoeconomiepolitique.org), or André Orléan's lecture on youtube.

18 John Locke, An Essay concerning Human Understanding (1689). London: Penguin, 1997, p. 89, Livre 2, chapitre 1 (" of Ideas in General, and their Originals " $\$ 1-5$ ): "I know it is a received doctrine that men have native ideas $(.$.$) . This opinion I have at large examined$ already". 
is the soul that provides us with these images and these shapes, the only ones, in the last analysis, that make it possible to know the object. ${ }^{19}$

On the grounds of his own inner experiences, the psychologist then chooses to go back to the very notions which Locke had discarded from his philosophical investigations, the supra-material and the innate:

In my opinion, it is grossly mistaken to suppose the soul of a new-born baby to be a tabula rasa, in the sense that it would not contain anything. [The child] does not bring to the impressions coming from outside any kind of disposition, but specific dispositions, which obviously supposes a particular choice and a certain shaping of the process of perception. These dispositions can be proved to be instincts and inherited preformations. Pre-formations are conditions of the process of perception that are grounded in instincts. They are a-priori and formal. They are the archetypes which define specific ways for any activity of the imagination. ${ }^{20}$

Of the collective subconscious, indeed, we can only observe the diverse manifestations in dreams, synchronicity, mythologies, alchemy, mystical discourses, etc. Its supra-material dimension places Jung at the heart of a debate of tremendous consequences in the history of ideas, that which finds its archetypal literary expressions

19 C.G. Jung, C. G., La Réalité de l'âme, 684-5: Un préjugé général veut [...] que le fondement essentiel de notre connaissance soit exclusivement donné de l'extérieur, ef que nihil esse in intellectu quod non antea fuerit in sensu (il n'y a rien dans I'intellect qui n'ait été auparavant dans les sens). Et pourtant [... tous ceux qui connaissent l'ancienne science ou l'ancienne philosophie de la nature savent quelle part de données psychiques se trouve projetée dans l'inconnu du phénomène extérieur. Cette part est en fait si grande, qu'en fin de compte nous ne sommes jamais en mesure d'indiquer la manière dont, en définitive, le monde lui-même est fait, car nous sommes bel et bien contraints de transposer l'élément physique dans un processus psychique, du moment que nous voulons parler de connaissance. [...] C'est l'âme qui nous offre ces images et ces formes, les seules qui, en définitive, rendent possible la connaissance de l'objet.

20 ibidem, 694-5: C'est à mon avis une grossière erreur de supposer que l'âme d'un enfant nouveau-né est une tabula rasa, en ce sens qu'elle ne contiendrait rien. [L'enfant] n'apporte pas aux impressions venant de l'extérieur n'importe quelles dispositions, mais des dispositions spécifiques, ce qui suppose évidemment un choix propre et un modelage de l'aperception. On peut prouver que ces dispositions sont des instincts ef des préformations hérités. Les préformations șont des conditions de l'aperception fondées sur des instincts, a priori ef formelles $[. .$.$] : ce sont les archétypes qui assignent leurs voies déterminées à toute activité$ de l'imagination... 
in Hamlet's famous monologue "To be, or not to be", or in Stevenson's novel Dr Jekyll and Mr Hyde, for instance. In modern times, yet another manifestation of this archetypal opposition is to be found in the confrontation between spiritualists like William Blake, who claim that "Mental things are alone real" (K617), and the advocates of a purely materialistic definition of reality, such Jacques Monod, who asserts that science is grounded on "the postulate of the objectivity of nature." We are faced with an aporia. But beyond this duality, the solution of which will necessarily be grounded in a mere feeling of truth, what is truly at stake is, according to Jung, nothing less than a collective neurosis on the scale of western civilization:

Nothing is more likely to alienate man from the fundamental field of his instincts than his capacity for learning, which turns out to be truly an impulse towards a progressive transformation of human behaviour. [...] [this capacity for learning] is also the source for numerous psychic difficulties and troubles, the cause of which lies in the fact that man grows more and more distant from his instinctive bases: thus uprooted, he identifies himself to the conscious knowledge he has of himself, and consequently to his conscience only, at the expense of the subconscious. [...]. He is thus led to forget himself, that is, to lose sight of his original instinctive nature, and [...] he substitutes the conception he has built of himself for his real essence. ${ }^{22}$

With this statement, Jung puts forward a deeply grounded criticism of western civilisation as it was defined in the wake of the so-called "Enlightenment". This is where the study of mysticism does have a bearing on our everyday lives. To put it in a nutshell, the scientific model of investigation has long been associated with the notion of progress (particularly in the wake of the industrial revolution), and David

21 See Jacques Monod, Le Hasard ef la nécessité. Paris : Sevil, 1970, 37-8 : La pierre angulaire de la méthode scientifique est le postulat de l'objectivité de la Nature. C'est-à-dire le refus systématique de considérer comme pouvant conduire une connaissance uvraie" toute interprétation des phénomènes donnée en iermes de causes finales, c'est-à-dire de projet [...]. Postulat pur, à jamais indémontrable, car il est évidemment impossible d'imaginer une expérience qui pourrait prouver la non-existence d'un projet, d'un but poursuivi, où que ce soit dans la nature.

22 C.G. Jung, Présent et avenir, Paris : Buchet-Chastel, 1962, 76-7 : Rien n'est plus susceptible de rendre l'homme étranger au plan fondamental de ses instincts que sa capacité d'apprendre, qui se révèle être en propre une impulsion à une transformation progressive des comportements humains. [...] [Cefte capacité d'apprendre] est aussi la source de nombreuses difficultés et perturbations psychiques qui ont pour cause le fait que l'homme s'éloigne de plus en plus de ses bases instinctives : déraciné, il s'identifie avec la connaissance consciente qu'il a de luimême, et par conséquent avec sa seule conscience à l'exclusion de l'inconscient. [...] |l en arrive à s'oublier lui-même, c'est-à-dire à perdre des yeux sa nature instinctive originelle, ef [...] il substitue à son essence réelle la conception qu'il s'est fabriquée de lui-même. 
Hume himself aimed at making it the model for his own investigations on human nature. ${ }^{23}$ But the model rests on the a-priori denial of elements that belonged to a long-standing tradition (since Socrates and Plato), and, from a psychological point of view, on a lack of balance between the four faculties of the mind. ${ }^{24}$

This point is a new occasion for observing parallels between mystical discourses and Jung's psychology. In a striking echo to Jacob Boehme's four primal forms of nature acquiring their own will, Blake's vision represents the fall of universal man as caused by the separation of his four "emanations", called the four Zoas: Urizen stands for Reason, Tharmas for sensation, Luvah for Love \& emotions, Urthona for Imagination. The prophetic poems describe at length their battles and further emanations (the fall into the many), and eventually their return to unity through the symbolical figures of Christ and Jerusalem. ${ }^{25}$ Now, these spiritual entities match exactly the four faculties of the mind which Jung identified much later on the basis of his clinical evidence: "Sensation tells us what really exists. Thought enables us to know the significance of what exists; feeling, what is its true value; and intuition at last points to the possible origins and ends that lie in what exists now.

From a psychological point of view, cases of lack of balance between these faculties can be seen in Plato (with the dominance of Reason); Locke (dominance of reason and sensation); romanticism (dominance of feeling); madness or religious fanaticism (dominance of uncontrolled intuition). From a mystical point of view, to William Blake in particular, given the occult theosophical mathematics according to which $4=4+3+2+1=10=1+0=1$, the figure 4 bears in itself the potentiality of a return to the One, symbolized by Jerusalem.

But Jung's considerations go even further into the phenomenological perspective: the subjectivity which is inherent to all systems of human knowledge leads him to regard the human psyche as intrinsically bound up in a world of psychic representations of the world. He is thus led to regard each representation as a phenomenon of conscience to be studied, whether it be a mystical vision, a religious discourse, a political ideology, a philosophical system, or a scientific explanation (much in the same way as Blake defined spiritual progression through "states" as

23 See David Hume's introduction to his book : A Treatise of Human Nature (1740)

24 See Patrick Menneteau, "La Sensation et la réflexion selon John Locke, ou la rhétorique au service de la séduction ", colloque international "la séduction " de l'université de Paris IV, janvier 2008 : published in XVII-XVIII, n65 (2008), 131-153.

25 See Patrick Menneteau, "William Blake \& Carl Gustay.Jung" in Problèmes actuels de Philologie : procédés méthodiques de l'enseignement des langues étrangères, actes du colloque international scientifique et pratique de l'université pédagogique de Novossibirsk, Faculté des Langues Etrangères, novembre 2006 
materializations of errors) $)^{26}$ If Jung never said "God exists", it is because, to him, as for many mystics, ultimate "reality" definitely escapes our grasp; except in experiences of a particular kind, the so-called "numinous experiences" that lie beyond words.

As a direct philosophical consequence, he relinquishes Plato's search for a definitive discourse on universal truth. But more importantly, he acknowledges that all discourses are ultimately grounded on a feeling whose nature is similar to a mystical experience of illumination (that is, based on the faculty of intuition), which confirms that the original feeling of truth is what matters. The concomitant step is to go beyond the simple use of sensation and reason (as in Locke's materialistic perspective, or in Freud's scientific claim), and to open oneself up to these manifestations of the subconscious (whatever it may be it itself), thus re-establishing the legitimacy of the faculty of intuition which modern man has neglected. To Jung, the link with mysticism is natural:

The man of religion enjoys a great advantage in that he is in a position to answer the present question which looms in front of us: he has at least a clear idea of the ground for and legitimization of, his subjective existence in its relationship to 'God'. I write 'God' between inverted commas to show that I mean an anthropomorphic representation the dynamics and symbolic values of which are transferred onto us through this medium which is the subconscious psyche. [...] It is no longer necessary to prove that there exist experiences of a truly religious kind. But is the ground for these experiences really what metaphysics or human theology call God or gods? This is the question that will always remain unanswered. ${ }^{27}$

26 See William Blake, in A Vision of the Last Judgment: "Whenever any Individual Rejects Error \& Embraces truth, a Last Judgment passes upon that Individuals (in Complete Writings. Oxford University Press, 1972, 613)

27 C.G. Jung. Présent et avenir, 86 : L'homme religieux jouit d'un immense avantage en ce qu'il peut apporter une réponse à la question actuelle qui plane menaçante sur nous: il a au moins une idée claire du fondement et de la légitimation de son existence subjective dans sa relation à 'Dieu'. J'écris 'Dieu' entre guillemets pour indiquer par là que j'entends une représentation anthropomorphe, dont la dynamique et la symbolique nous sont transmises par ce milieu qu'esł la psyché inconsciente. [...] II n'est plus nécessaire de prouver qu'il est des vécus qui sont des expériences religieuses. Mais est-ce que le fondement de ces expériences est bien foujours réellement ce que la métaphysique ou la théologie humaine appellent Dieu ou les dieux? Voilà ce qui restera l'objet d'un éternel point d'interrogation. Mais celte question au fond est vaine et comporte elle-même sa réponse, de par la numinosité subjectivement bouleversante de l'événement vécu. Quiconque a vécu une telle expérience est comme 'saisi' par elle et c'est pourquoi il n'est pas en état de s'abandonner à des considérations stériles d'ordre métaphysique ou de l'ordre de la théorie de la connaissance. 
Beyond these philosophical or religious considerations, what matters, therefore, is to focus primarily on the original inner experience of the subject. Jung adds on:

But this question is vain at the bottom and carries its answer within itself, thanks to the subjectively upsetting numinosity of the experience. Anyone who has lived through such an experience is as it were 'seized' by it, and consequently cannot indulge in sterile considerations of a metaphysical order or related to any theory of knowledge. ${ }^{27}$

Thus justified in passing from the strictly materialistic frame of empiricism and science to the acknowledgement of inner experience as a grounding factor, we must now try to determine how far our new perspective may reach.

\section{Mysticism without bounds: a possibility or a danger? The psychological dimension of mysticism.}

In other words, does madness necessarily lie beyond the bounds of mysticism? The next step consists in asking whether inner experience can provide sufficient guidance for man's values and behaviour. John Locke's warning against the possession of the mind by gods, the distance sought by the philosophers of the Enlightenment to avoid the dangers of "enthusiasm", have not kept a Hitler from harbouring a deep conviction that he was right, nor prevented modern confrontations between Protestants and Catholics, Muslims, Hindus, and Jews, which fuel our daily news reports. ${ }^{28}$ The challenge to avoid the phenomenon of religious fanaticism (which, in some cases, leads to the negation of human life), madness and solipsism remains, hence the need for a certain degree of rational control, that is, for keeping a balance between the four faculties that act as sources of information for conscience.

28 See David Hume, Dialogues concerning Nafural Religion (1779), London: Penguin Books, 1990, 131: "Factions, civil wars, persecutions, subversions of government, oppression, slavery; these are the dismal consequences which always attend [religion's] prevalence over the minds of men." See also John Locke, An Essay concerning Human Understanding (1690), Glasgow: Collins, 1984, 429-30: Rise of Enthusiasm. Immediate revelation being a much easier way for men to establish their opinions and regulate their conduct than the tedious and not always successful labour of strict reasoning, it is no wonder that some have been very apt to pretend to revelation, and to persuade themselves that they are under the peculiar guidance of heaven in their actions and opinions, especially in those of them which they cannot account for by the ordinary methods of knowledge and principles of reason. Enthusiasm. Their minds being thus prepared, whatever groundless opinion comes to settle itself strongly upon their fancies is an illumination from the Spirit of God, and presently of divine authority; and whatsoever odd action they find in themselves a strong inclination to do, that impulse is concluded to be a call or direction from heaven, and must be obeyed; it is a commission from above, and they cannot err in executing it. 
This is indeed the central stake in the process of individuation as a life-long attempt at confronting the subconscious [the 'not-yet known'], and reconciling conscience and the subconscious; integrating the subconscious into a wider conscience: the Self. David Hume initiated the rational enquiry into the original subjective experience which grounds a man's belief. He thus made it possible and necessary to acknowledge the part of subjectivity, even in those discourses that claim to objectivity, and this operation was developed in the phenomenology of Husserl, ${ }^{29}$ which renews the Socratic "know thyself" precept.

Jung offen insists on the need to exert the control of reason over the sometimes intrusive images coming from the subconscious, for the risk of being overcome by madness is real. Indeed, he finds the substance for this attempt at rationalisation in alchemy, in mythologies, religions, and, more particularly, in mystical discourses. As soon as he tries to keep a trace of his experience casting it into comprehensible linguistic forms, the mystical author starts performing a rational task.

In this respect, the absence of an overwhelming mystical experience in a subject may even be regarded as an advantage, for it enables one to keep a certain critical distance, and to compare various experiences without being overwhelmingly 'seized' by them. Mystical discourses provide a rich set of accounts of such 'numinous' experiences, and we may look for what they can teach us about ourselves. Our response to a mystical discourse, the echo it will awake in us, is an indication as to what we are, or more exactly as to our state. As Jacob Boehme wrote: "I must exhort the intellect to have a good look into the mirror of intelligence and to contemplate what it is; and to accept to renounce its plan for the senseless building of Babel; it is high time it did so." ${ }^{\prime 30}$

In the renewal of the "know thyself" Socratic precept, many examples of readings and responses can be seen as depending on the subject's predisposition. In the perspective of Lockian materialism, for instance, mystical discourses are a simple

29 See: Edmund Husserl, The Crisis of European Sciences and Transcendental Phenomenology (1913), Northwestern University Press, 1970, 90: Through Berkeley's and Hume's revival and radicalization of the Cartesian fundamental problem, "dogmatic" objectivism was, from the point of view of our critical presentation, shaken to the foundations. This is true not only of the mathematizing objectivism, so inspiring to people of the time, which actually ascribed to the world itself a mathematical-rational-in-itself (which we copy, so to speak, better and better in our more or less perfect theories); it was also true of the general objectivism which had been dominant for millennia.

30 Jacob Boehme, Mysterium Magnum, vol I, 104: Je dois exhorter l'entendement à regarder une bonne fois dans le miroir de l'intelligence et à contempler ce qu'il est; et à bien vouloir abandonner son projet de construction insensée de Babel; il en est grand temps. 
matter of illusion (Freud belongs to this interpretative trend). ${ }^{31}$ In the religious perspective, mystical discourses are genuine testimonies of direct encounters with God, for instance in the Theologia Germanica. ${ }^{32}$ In the Jungian perspective, mystical discourses are allegorical exemplifications of the process of individuation. According to Steve Melanson, Jung's reading of mystical authors may even lead to the definition of a modern form of mysticism that addresses each and every one of us. ${ }^{33}$ Through such common notions as "detachment" (from sensation and intellect), divine incarnation as God's birth in the soul, and the mirror, mystical discourses can be read as allegories for the process of individuation, much in the same way as Jung interpreted the discourse of alchemy.

One result is that even when faced with civilisation or global problems, one should prefer individual "progress" to solutions of general systems, whether ethical, religious or metaphysical, political or economic. The confrontation with our own inner experience enables us to become aware of a deeper self: "such an experience will prove to some the truth of Christ, to others, the truth of Buddha, and this to the utmost violence" ${ }^{34}$

In this second stage of phenomenological reflection, we can become aware of the reason why mystical discourses may vary and even contradict one another (which, in the eyes of the philosophers of the Enlightenment, for a matter for disqualification): "it is only a question of the phenomenology of so-called psychic dominants, whether they be named God, Allah, Buddha, Purusa, Zeus, Planets, the Zodiac or sexuality". ${ }^{35}$ Thus, as was pointed out before, there is no longer any quest for a universal truth: "[...] what is valid for oneself is absolutely not so for other individuals with a different psychology. We are in any case far removed from a system of explanation that would be universally valid. ${ }^{\prime 36}$

31 See what Freud has to say about it in L'Avenir d'une illusion; and remember Marx, to whom religion was the opium of the people.

32 See the quotation at the beginning of this paper.

33 Steve Melanson. Jung et la Mystique, Vannes: Sully, 2009.

34 Jung, C.G., Psychologie et Alchimie, Paris : Buchet-Chastel, 1970, 23 (quoted in Steve Mélanson. Jung et la mystique, p.63) : " une telle expérience prouvera, pour les uns, la vérité du Christ, pour les autres, la vérité du Bouddha, et cela jusqu'à la plus extrême évidence. "

35 Jung, C.G., Le Divin dans I'homme, Paris : Albin Michel, 1999, 209 (quoted in Steve Mélanson. Jung et la mystique, p. 68) : "c'est uniquement une question de phénoménologie des dominantes dites psychiques, qu'elles se nomment Dieu, Allah, Bouddha, Purusa, Zeus, Planètes, Zodidque ou Sexualité. "

36 Jung, C. G., L'Ame et le Soi, Paris : Albin Michel, 1997, 177 : « ...ce qui vaut pour soi ne vaut absolument pas pour d'autres individus possédant une psychologie différente. Nous sommes donc en tous les cas fort éloignés d'un schéma d'explication qui serait partout valable ". 
In particular, Jung takes into account the fundamental differences between the Western and Eastern conceptions of mysticism:

The Christian western world regards man as totally submitted to God's grace, or at least to the church as the only earthly instrument of redemption acknowledged by God. The East, by contrast, remains strong it its belief that man himself is the sole cause for his development; for the East believes in 'self-deliverance'. (..) For us, man is infinitely small, and grace is everything; in the East, man is God and delivers himself. ${ }^{37}$

To Jung, we are indeed prisoners of our own psychic world, in which our perceptions and thoughts are determined by innate archetypes in us, hence the commons forms in the multiple mythologies of the world. Beyond the apparent variety and contradictions between the different mystical discourses, there exists a deep underlying unity. They can all be seen as manifestations of the collective subconscious through an individuation process that leads to the "Self" (sometimes called "God")... In the course of this rational analysis, phenomenology defines the concept of the regard constituant (which is taken up by C.G. Jung when he observes that our conscience is enclosed in a world of psychic representations): there is no longer such a thing as an outside object of study. Every system relies, in the last analysis, on a "constituting outlook" which reflects the subject's inner being and "reality": in this sense, every mystical discourse is a projection, a manifestation of the inner deep-seated "reality" of its author. "Every Eye Sees differently. As the Eye, Such the Object," as William Blake said. ${ }^{38}$

Yet, in the end, the choice between the readings of a mystical experience as a manifestation of God or as a projection of the human subconscious is itself a matter of subjective response and constituting outlook: mystics are not academics, and vice-versa! Just as it might be dangerous to lose control over a mystical experience, imposing too strict a restraint over it can reduce it to merely human dimensions. It is time to ask whether psychology reduces mysticism to its own earthly dimensions, or whether mysticism should be left to lead one to madness.

37 Jung, C. G., Psychologie et orientalisme. Paris, Albin Michel, 1985, 136 et 137 (quoted in Steve Mélanson. Jung ef la mystique, 155) : L'Occident Chirétien considère l'homme comme tout à fait soumis à la grâce de Dieu ou du moins à l'église, seul instrument terrestre de la rédemption qui soit reconnu par Dieu. L'Orient, en revanche, persiste à croire que l'homme lui-même est la seule cause de son développement; car l'Orient croit en 'I'auto délivrance'. (...) Chez nous, l'homme est infiniment petit, et la grâce est tout ; en Orient, l'homme esł Dieu et se délivre lui-même.

William Blake, Complete Writings, 456. 


\section{The mystical dimension of psychology: "mysticism unbound".}

The boundaries between the two fields seem to disappear, thus leading to the final questions: are we, in the end, to give prevalence to the mystical or to the psychological discourse? Are Jung's psychological considerations a mere imitation of the themes of mysticism (Gnostic, in particular), to which he frequently refers? Or are they an invitation to beware of alluring illusions? Our working hypothesis will be that both discourses proceed from the manifestation of the same archetypes (the "reality" of which cannot spoken of), for instance, that of our spiritual desire to overcome death, because death is the negation of all meaning to material life (in which sense the tragic universe of astronomy can be read as a projection of the despair of materialist scientists). More fundamentally, all these discourses end up in displaying the conception of man as a mirror to a manifestation that vastly outgrows human dimensions.

Jacob Boehme, for instance, wrote: "There is not one thing that can be God, but God's formed and expressed being, a mirror to the spirit that is called God, in which the spirit manifests itself and, in the joy of his own image, plays with this manifestation which is his created being. ${ }^{\prime \prime} 9$ Angelus Silesius echoed the idea in the following words: "I carry God's image: if He wants to contemplate Himself./ $\mathrm{He}$ can only do so in me, He that resembles me. ${ }^{40}$

And we can also read in the Theologia Germanica:

When one acknowledges that Perfection is only the Whole, above everything, it necessarily follows that one ascribes all good, such as being, life, knowledge, power and everything, solely to this Perfection and not to creatures. This is when true inner life begins. In this process, God Himself becomes man, so that there is nothing that be from God, nor God's, nor nothing that take possession of something. It is only

39 Jacob Boehme, Mysterium Magnum. vol. I, 103 : "II n'y a aucune chose qui soit Dieu mais bien l'être formé et exprimé de Dieu, un miroir de l'esprit qui s'appelle Dieu, où l'esprit se manifeste et, dans la joie qu'il a de lui-même, jove avec cette manifestation qui est son être crée." "

40 Angelus Silesius, Le Pèlerin chérubinique, (premier livre, distique 105, 40, as quoted in Steve Melanson. Jung et la mystique, 127): Je porte l'image de Dieu : $s^{\prime} l l$ veut se contempler/II ne peut le faire qu'en moi, Celui qui me ressemble. 
God, the eternal, unique and perfect Good who is there, who lives there, who knows there, loves, can, wills, does and forgets. ${ }^{41}$

This typically mystical idea William Blake condensed in a much shorter formulation: "God only Acts \& Is, in existing beings or Men". ${ }^{42}$ And, since archetypes also shape the scientist's ideas, we also find it manifested in the discourse of modern astronomy, as when Hubert Reeves, after describing the original chaos that followed the Big Bang, writes:

The billions of billions of particles which compose us are associated, ordered and combined in an organism of a daunting complexity, the behaviour of which is still widely unknown. Thanks to this organization, we are in a position to perceive, and become aware of, our surrounding world. The history of the universe can be told as the tale of this extraordinary metamorphosis. ${ }^{43}$

In this discourse of science, astronomical events since the Big Bang and the evolution of the species on planet earth lead to the emergence of a conscience of the universe through man: this vision is a way of re-injecting meaning in an otherwise tragic universe bound for annihilation, ${ }^{44}$ by calling upon an archetype:

This discussion leads to a paradoxical situation. As a product of biological evolution, man is undoubtedly part of nature. Yet, by comparison with all living beings, his extraordinary level of performance is an invitation to grant him special status. We can, in a certain way, regard him as standing outside nature. This dual situation is a source for ambiguity.

41 Théologie Germanique (éd. M. Windstosser), Paris : Arma Artis, 1911, 214 :Lorsqu'on reconnait que le Parfait est uniquement le tout et au-dessus de tout, il en suit nécessairement qu'on attribue tout bien, comme l'être, la vie, la connaissance, le savoir, le pouvoir et toute chose, uniquement à ce Parfait et non aux créatures. C'est alors que commence la vraie vie intérieure.

42 William Blake, Complete Writings, 155.

43 Hubert Reeves, Malicorne, réflexions d'un observateur sur la naiure, Paris : Seuil, 1990, 153 : Les milliards de milliards de particules dont nous sommes faits sont associées, agencées, combinées dans un organisme d'une complexité fantastique, dont le comportement nous échappe encore largement. Grâce à cette organisation, nous sommes en mesure de percevoir, et de prendre conscience du monde qui nous entoure. L'histoire de l'univers peut être racontée comme le récit de cette extraordinaire métamorphose.

44 See, for instance: L. Wolpert, The Unnatural Nature of Science (1992), London: Faber and Faber, 1993, 146-7: (In the vision of a universe bound for annihilation): the scientist, or anyone else without religion, has to face an indifferent chaos and has to accept that all human hopes and fears, all ecstatic joys and dreadful pains, all the creative torments of scholars, artists, and saints and technicians, are going to vanish for ever, without trace. 
Biologist Jean Dausset writes: 'Nature does not speak, it is man that speaks.' It would be equally justified to say that man gives a voice to nature. ${ }^{45}$

In the end, indeed, man is that through which nature becomes conscious: "[Nature] pervades the field of values. Through the advent of moral sense in man, its eyes are open and it becomes responsible. Man is the conscience of nature. ${ }^{46}$ And C.G. Jung takes up the same image in psychological terms:

By virtue of his faculties of reflection, man has raised himself above the animal world, and through his spirit, he is proof that, precisely in the fact of the development of conscience, nature has invested a lot in him. Thanks to this development, he takes possession of nature, acknowledges the existence of the world, and, in so doing, confirms it to the Creator. Thus, the world becomes a phenomenon, which it could not be without a conscious reflection. If the Creator were Self-conscious, he would not need conscious creatures. [...] This is where the miracle of reflected conscience creeps in, the second cosmogony. Conscience matters so much that one cannot help supposing that the element of meaning probably lay hidden in all the drama of this monstrous and apparently senseless biological evolution. Meaning at last has found, as if by chance, a means of self-manifestation at the warm-blood level of the differentiated brain, not in any intentional nor predicted way, but in a fashion that was foreshadowed through an 'obscure impulse', both intuitive and tentative.[...] The hypothesis of a latent meaning provides man with a cosmogonic significance, a true "raison d'être" ${ }^{47}$

45 Hubert Reeves. opus cit,, 157:Cefte discussion nous mène à une situation paradoxale. En tant que produit de l'évolution biologique, l'être humain fait indubitablement partie de la nature. Pourtant, en regard de l'ensemble des êtres vivants, son extraordinaire niveau de performance nous invite à lui accorder un stalut spécial. On peut, d'une certaine façon, le considérer comme hors de la nature. Cette double situation est une source d'ambiguité. Le biologiste Jean Dausset écrit : 'La nature ne parle pas, c'est l'être humain qui parle.' II serait tout aussi défendable de dire que l'être humain donne une voix à la nature.

46 Ibid. 162: " [la nature] investit le domaine des valeurs. Par l'avènement du sens moral chez les humains, elle ouvre les yeux et devient responsable. L'homme est la conscience de la nature".

47 C.G. Jung, Ma Vie.p. $384-5$ et 427 : En vertu de ses facultés de réflexion, l'homme s'est élevé hors du monde animal et, par son esprit, il démontre que, précisément dans le fait du développement de la conscience, la nature a investi un grand prix en lui. Grâce à ce développement, il s'empare de la nature, reconnaît l'existence du monde, et, par cela même, le confirme en quelque sorte au Créateur. De ce fait, le monde devient un phénomène, ce qu'il ne serait pas sans réflexion consciente. Si le Créateur éfait conscient de Lui-même, il n'aurait nul besoin de créatures conscientes. [...] C'est ici que se glisse le miracle de la 
In the end, Jungian psychology finds in mysticism further ground for taking into account of experience of intuition, while acknowledging that this faculty is only one among four, the balance of which should be respected. Mysticism also provides an opportunity for reasserting the legitimacy of supra-materialism in the face of Locke and his followers (and modern western civilization). Rational analysis enables the phenomenologist psychologist to account for the contradictory multiplicity of mystical discourses in terms of the subject's disposition or state; and rationalizing mystical experiences makes it possible to integrate the archetypes of the subconscious into conscience, thus opening the way towards the larger personality of the "Self". This is making the fruits of mysticism accessible even to those who do not receive "grace": there is no "elitism" in Jungian psychology, much in accordance with Blake's prophetic poetry when it stated: "Every honest man is a prophet" ${ }^{48}$ Jung reasserts the legitimacy of mystical discourses and their link with everyday life, without reducing them to the dimension of projections of sexual fantasies: if he calls "God": the "Self" or the "subconscious", the meaning is the same, and the life-long process of individuation reintroduces meaning into life by acknowledging the co-existence of its two dimensions, corporeal and spiritual.

To conclude, contrary to what a Freudian psychoanalytical interpretation could suggest, sexual imagery in mystical texts is not necessarily a projection of man's sexual fantasies, but may symbolically refer to the primal spiritual realities of creation (which by all accounts escape our apprehension). To Jacob Boehme, indeed, the visible world is a symbol for the invisible ${ }^{49}$ hence the determining character of the choice between materialism and supra-materialism, which will determine our reading of the world, on the ground of a feeling of truth.

The main contribution of mythologies, religions, and attention paid to the subconscious generally (as the "not yet known") is that they can provide efficient

conscience réfléchie, seconde cosmogonie. L'importance de la conscience est tellement vaste que l'on ne peut s'empêcher de supposer que l'élément sens gisait probablement caché dans toute la mise en scène biologique, monstrueuse et apparemment insensée, sens qui a enfin trouvé, comme par hasard, à se manifester à l'échelon du sang chaud et du cerveau différencié, non pas de façon intentionnelle ni prévue, mais comme pressentie à travers une 'impulsion obscure', intuitive et fâtonnante. [...] L'hypothèse d'un sens latent confère à l'homme une signification cosmogonique, une véritable 'raison d'être',

48 William Blake, Complete Writings, 392.

49 See Jacob Boehme, Mysterium Magnum, vol. 1, 49: Si nous considérons le monde visible avec son être ef que nous considérons la vie des créatures, nous y trouvons alors un symbole du monde invisible selon l'esprit qui est latent dans le monde visible comme l'âme dans le corps, et nous voyons que le Dieu caché est proche de toit et compénètre tout, tout en restant parfaitement caché à l'être visible. 
antidotes against the tragedy of modern conscience, which, according to Jung, is severed from its roots. Being a source for meaning, these roots can be a source for ethics, and as such point to the shortcomings of the techno-scientific vision of the world, economic globalisation, the consumer society with its inbred lack of respect for "mother nature", and the widening gap between rich and poor (which is the antithesis of a humanity in quest of a unified whole!).

The Jungian reading of mythological and mystical discourses is not an attempt to reduce them to the dimensions of psychology: rather, it aims at reasserting their value and legitimacy in a world that tends to disregard them as "disconnected" with reality, and is apparently unable to stop its meaningless race towards catastrophe. The archetype of the mirror, at play in mysticism and psychology (and even in science) implies that man, even if he is a necessary instrument for a manifestation of cosmic dimensions, can no longer claim to be the focal point of creation, nor an end in himself. Individuation enables the subject to reach beyond the individual, towards the universal in which he is no longer the same individual.

In the end, may I humbly suggest that talking about mysticism in a country in which human misery can still be seen in its most cruel forms is not beside the point: for it is in countries such as this, in which immemorial traditions are still at hand, that lies the last possibility for modern mankind to find the means and the strength to give a new orientation to the western model of development, even as it claims to become global, bearing in mind the supra-material stakes defined by mysticism (without bounds), as expressed for instance in these lines about God: "Nowhere is he far from something or close to it, $\mathrm{He}$ is everywhere and in everything, his bith takes place everywhere, and outside him nothing exists. He is time and eternity, cause and absence of cause, and only true intelligence which is none other than God himself may grasp him." ${ }^{0}$ This task, which aims at the level of civilization, mirrors the main stakes of the process of individuation on a personal level: it also requires the mediation of reason, which is why Jung preferred the concept of the subconscious to that of God: "I prefer the term « subconscious ", perfectly knowing that I could as well speak of 'God' or 'demon' if I wanted to express myself mythically. ${ }^{\prime 51}$

50 Jacob Boehme, Mysterium Magnum, vol 1, 57: Nulle part il $n$ 'est loin ou près de quelque chose, il est par Tout et en Tout, sa naissance est partout, et en dehors de lui il n'existe rien. Il est le temps et l'éternité, la Cause et l'Absence de cause, et seule peut l'étreindre l'intelligence véritable qui n'est autre que Dieu lui-même

51 C.G. Jung, Ma Vie, 382-3 : "...je préfère le terme d"inconscient", en sachant parfaitement que je pourrais aussi bien parler de 'Dieu', ou de 'démon', si je voulais m'exprimer de façon mythique ". 


\section{Bibliography}

1. Blake, William, Complete Writings (1783-1820), ed. Geoffrey Keynes, Oxford University Press, 1972.

2. Boehme, Jacob, De la Triple vie de I'homme (written in 1620, published in 1682), Plan de la Tour, Edifions d'aujourd'hui, 1982.

3. Boehme, Jacob, Mysterium Magnum (1623), Plan de la Tour: Editions d'aujourd'hui, 1978.

4. Carnap, Rudolph, "Theories and Nonobservables" in J. Fetzer, ed. Foundations of Philosophy of Science, New-York: Paragon House, 1993.

5. Cazenave, Michel, La Science ef les figures de l'âme, Monaco, éd. Du Rocher, 1996.

6. Hume, David, A Treatise of Human Nature (1739), Oxford: Clarendon Press, 1983

7. Hume, David, Dialogues concerning Natural Religion (1779), London: Penguin Books, 1990

8. Husserl Edmund. The Crisis of European Sciences and Transcendental Phenomenology (1913), Northwestern University Press, 1970.

9. Jung C.G., Le Divin en l'homme, Paris: Albin Michel, 1999.

10. Jung, C.G., Ma Vie (1961), Paris: Gallimard, 1973.

11. Jung, C.G., Présent et avenir, Paris: Buchet-Chastel, 1962.

12. Jung, C.G., Psychologie ef Alchimie, Paris: Buchet-Chastel, 1970.

13. Jung, C.G., Psychologie ef orientalisme, Paris, Albin Michel, 1985.

14. Jung, Carl Gustav, L'Ame et le Sol, Paris: Albin Michel, 1997.

15. Lardreau, Guy, Discours philosophique et discours spirituel: autour de la philosophie spirituelle de Philoxène de Mabbourg, Paris: Sevil, 1985.

16. Locke, John, An Essay concerning Human Understanding (1689), London: Penguin, 1997.

17. Melanson, Steve, Jung ef la Mystique, Vannes: Sully, 2009.

18. Monod, Jacques, Le Hasard ef la nécessité, Paris: Seuil, 1970.

19. Reeves, Hubert, Malicorne, réflexions d'un observateur sur la nature, Paris: Seuil, 1990.

20. Théologie Germanique, ed. M. Windstosser, Paris: Arma Artis, 1911.

21. Wolpert, L., The Unnatural Nature of Science (1992), London: Faber and Faber, 1993. 